\title{
Inhibitory activity of Varronia curassavica and Mikania laevigata fractions against pathogens associated with persistent dental infections
}

\author{
Loiane Massunari ${ }^{1}$, Amanda C. A. Souza1, Paula F. K. Domingues', Juhan A. Scardelato², \\ Luis V. S. Sacramento ${ }^{2}$, Eloi Dezan-Junior ${ }^{1}$, Cristiane Duque ${ }^{1 *}$ (D) \\ ${ }^{1}$ Departamento de Odontologia Preventiva e Restauradora, Faculdade de Odontologia de Araçatuba, Universidade Estadual \\ Paulista "Júlio de Mesquita Filho" (UNESP), Araçatuba, SP, Brasil \\ ${ }^{2}$ Departamento de Princípios Ativos Naturais e Toxicologia, Faculdade de Ciências Farmacêuticas de Araraquara, Universidade \\ Estadual Paulista "Júlio de Mesquita Filho" (UNESP), Araraquara, SP, Brasil \\ *Corresponding author: cristiane.duque@unesp.br; cristianeduque@yahoo.com.br
}

\begin{abstract}
Herbal medicines have been studied as potential antimicrobial agents, emerging as treatments against oral diseases. The current study evaluated the antimicrobial activity of the crude extract and fractions of Mikania laevigata Schultz Bip. ex Baker (ML) and Varronia curassavica Jacq (VC) against oral pathogens associated with persistent dental root infections, under planktonic and biofilm conditions. Minimal inhibitory concentrations and minimal bactericidal/fungicidal concentrations were determined for the ML and VC fractions/extracts against Enterococcus faecalis, Actinomyces israelii, Pseudomonas aeruginosa, and Candida albicans using the microdilution method. The best results were chosen for subsequent biofilm assays. All tested ML and VC extracts/fractions demonstrated inhibitory activity against $E$. faecalis and $A$. israelii. The ML ethyl acetate fraction affected the growth of all microorganisms tested. C. albicans and $P$. aeruginosa were not affected by any VC extract/fractions. The ML ethyl acetate fraction eliminated $E$. faecalis, A.israelii, and $P$. aeruginosa biofilms after 24h. A similar result was observed for $\mathrm{ML}$ crude hydroethanolic extract and its hexane fraction for $A$. israelii. The VC hexane fraction was able to eliminate $A$. israelli biofilms. None of the tested extracts or fractions eliminated C. albicans biofilm. The Mikania laevigata ethyl acetate fraction is an efficient antimicrobial agent against oral pathogens and could be indicated for the treatment of persistent dental infections.
\end{abstract}

Keywords: Plant Extracts. Phytotherapy. Antimicrobial Activity.

\section{How to cite}

Massunari L, Souza ACA, Domingues PFK, Scardelato JA, Sacramento LVS, Dezan-Junior E, Duque C. Inhibitory activity of Varronia curassavica and Mikania laevigata fractions against pathogens associated with persistent dental infections. Rev Ciênc Farm Básica Apl. 2020;41:e686. https://doi.org/10.4322/2179-443X.0686

\section{INTRODUCTION}

The oral microbiota is formed by a complex ecosystem, which changes constantly throughout human life. Most of the microorganisms are commensal, however, they can cause disease in appropriate conditions. Dental caries and trauma allow the penetration of oral

Financial support: LM - received scholarship from CAPES (Coordenação de Aperfeiçoamento de Pessoal de Nível Superior, Brazil), CD - received financial support from CAPES.

Conflicts of interest: The authors have no conflict of interest to declare.

Received on August 23, 2020. Accepted on September 14, 2020. 
microorganisms into dentin tubules and the root canal system, causing pulp infections and, frequently, apical periodontitis with the formation of bone lesions (Persoon et al., 2017). Even after endodontic treatment, resistant microorganisms are trapped in the root canal system, requiring irrigants and dressings with a large spectrum of antimicrobial action (Siqueira \& Rôças, 2008). Specific bacteria such as Enterococcus faecalis and Candida albicans can be found in cases of endodontic treatment failure (Cogulu et al., 2008) and Actinomyces israelii and Pseudomonas aeruginosa in refractory periapical lesions (Siqueira \& Rôças, 2008).

Solvents such as water, butanol, hexane, and ethyl acetate have been used for the semi purification of the crude plant extract, from which various fractions have been obtained and studied for pharmaceutical purposes, including for controlling oral pathogens (Yatsuda et al., 2005; Michielin et al., 2009). Mikania laevigata SchultzBip. ex Baker, popularly known as "guaco", belongs to the Asteraceae family and the genus Mikania and is commonly found in southern Brazil. Several properties have been described for Mikania laevigata, including antiinflammatory and antimicrobial potential (Yatsuda et al., 2005; Duarte et al., 2007; Michielin et al., 2009). Another plant with therapeutic effects is popularly known as "ervabaleeira". The classification of "erva-baleeira" has been widely discussed and is still controversial; the accepted name in World Plants - Catalogue of Life (Hassler, 2020) and Brazilian Flora (Jardim Botânico do Rio de Janeiro, 2020) is Varronia curassavica Jacq., belonging to the genus Varronia and family Boraginaceae, with Cordia verbenacea and Cordia curassavica as synonyms. However, according to The Plant List (2013) and International Plant Name Index (2012) the accepted name is Cordia curassavica (Jacq.) Roem \& Schult. This species is native to Central and South America; and in Brazil it is commonly found in the Atlantic and Amazon Forests (Meccia et al., 2009). In the current study, we adopted the scientific name Varronia curassavica Jacq. based on its Brazilian origin, following the criteria of Brazilian Flora (Jardim Botânico do Rio de Janeiro, 2020). Varronia curassavica is widely used in popular medicine, mainly as an antimicrobial, anti-inflammatory, and analgesic agent (Matias et al., 2013). Thus, the aim of this study was to evaluate the antimicrobial activity of Mikania laevigata and Varronia curassavica crude hydroethanolic extracts and their aqueous, hexane, butanol, and ethyl acetate fractions against pathogens associated with persistent dental infections, under planktonic and biofilm conditions.

\section{MATERIAL AND METHODS}

Leaves of Mikania laevigata Schultz Bip. ex Baker and Varronia curassavica Jacq. were collected at the Medicinal and Toxic Plant Garden in the School of Pharmaceutical Science, UNESP, in Araraquara, São Paulo, Brazil (21 ${ }^{\circ} 48^{\prime} 51.4^{\prime \prime}$ S and $\left.48^{\circ} 12^{\prime} 05.1^{\prime \prime} \mathrm{W}\right)$ and authenticated on location by Prof. Dr. Luis V. S. Sacramento. The leaves were dried in an oven at $40^{\circ} \mathrm{C}$ for 96h. A portion of $10 \mathrm{~g}$ of dry extract was partitioned between 1:1 hexane: water, ethyl acetate, and n-butanol, in sequence. Fractions were separated and evaporated to dry. The solvents used to re-suspend the extracts and fractions were sterile distilled water for the crude extract, and aqueous, hexane, and butanol fractions and 5\% DMSO for the ethyl acetate fraction.

The present study used the following microbial strains kindly provided by the Oswaldo Cruz Foundation (FIOCRUZ - Rio de Janeiro, Sao Paulo, Brazil): Enterococcus faecalis (ATCC 51299), Actinomyces israelii (ATCC 12102), Pseudomonas aeruginosa (ATCC 15442), and Candida albicans (ATCC 26790). Microbial suspensions were prepared from overnight cultures in Brain Heart Infusion broth (BHI, Difco Laboratories, Kansas City, MO, USA) for bacteria strains or Sabouraud Dextrose broth (SD, Difco) for Candida albicans and incubated at $37^{\circ} \mathrm{C}$ for $24 \mathrm{~h}$ in a $5 \% \mathrm{CO}_{2}$ atmosphere.

MIC and MBC/MFC assays were conducted according to Balouiri et al. (2016). The final concentration of suspension in the wells was $5-10 \times 10^{5} \mathrm{CFU} / \mathrm{mL}$ for bacteria and $2.5-5 \times 10^{3}$ $\mathrm{CFU} / \mathrm{mL}$ for Candida albicans. First, the serially diluted plant extracts and fractions and microbial suspensions were inoculated in each well. The plates were incubated at $37^{\circ} \mathrm{C}$ for $24 \mathrm{~h}$ in $5 \% \mathrm{CO}_{2}$. The colonies were counted, and the number of viable bacteria was determined in CFU/ml. The MBC/MFC was considered when the extracts/fractions killed (99.9\%) of the 
tested microbial culture. Chlorhexidine digluconate $(\mathrm{CHX})$ and Amphotericin $\mathrm{B}(\mathrm{AB})$ were used as positive controls for the bacteria and C. albicans, respectively. Cultures without antimicrobial agents in MH broth or RPMI-1640 medium and 5\% DMSO were considered as negative controls. All experiments were performed in triplicate.

Biofilm assays were performed with the extracts/fractions that presented $100 \%$ growth inhibition in the MBC/MFC tests, except for C. albicans, as described by Massunari et al. (2017). Briefly, 96-well microplates, U-shaped bottom, were pretreated with $200 \mu$ l of artificial saliva

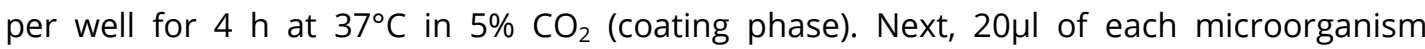
suspension $\left(1-5 \times 10^{6} \mathrm{CFU} / \mathrm{mL}\right)$ were inoculated in each well containing $180 \mu \mathrm{l}$ of $\mathrm{BHI}$ broth with $0.5 \%$ glucose for bacteria and SD broth with $0.5 \%$ glucose for Candida. The plates were incubated for $48 \mathrm{~h}$. Subsequently, $200 \mu \mathrm{l}$ of plant extract or fraction solutions ( $5 \mathrm{x}$ or $10 \mathrm{x} \mathrm{MBC}$ and MFC concentrations) were inserted in each well. After 24h of incubation, all wells were plated in Brain Heart Infusion agar for bacteria or Sabouraud Dextrose agar for C. albicans and incubated for $24 \mathrm{~h}$ followed by microbial counting.

Data from planktonic growth (MIC assays) were converted to logarithmic scale (log10 $(\mathrm{CFU}+1)$ and the percentage (\%) of microbial reduction compared to normal growth (control group) was calculated. Non-parametric data obtained in the biofilm assays were represented by box-whisker plots. Mann-Whitney tests were applied to compare one group with another and these with the positive controls (CHX or $\mathrm{AB}$ ) and solvent controls (DMSO and water) for biofilm assays.

\section{RESULTS AND DISCUSSION}

Species of the family Asteraceae and Boraginaceae have been broadly studied for the treatment of various human illnesses due to their wide-ranging pharmacological properties, such as antimicrobial, anti-inflammatory, anthelmintic, and analgesic action, (Matias et al., 2015). There are records of the use of "erva-baleeira" by traditional communities in the treatment of inflammation, muscle pain, arthritis, rheumatism, stomach ulcers, and others (Passos et al., 2007; Roldão et al., 2008; Miranda \& Hanazaki, 2008; Gandolfo \& Hanazaki, 2011). Popularly, the plant leaves are used in the form of infusion, decoction, tinctures, hydroalcoholic extracts, and others (Hartwig et al., 2020). "Guaco" is widely used by traditional communities for the treatment of flu and cough, made from leaves in the form of syrup and infusion (Oliveira \& Menini, 2012; Pinto et al., 2017). Due to the large number of ethnobotanical reports, a lot of research has been conducted to provide evidence of their pharmacological and biological properties (Matias et al., 2015).

The current study highlights the importance of investigating Mikania laevigata and Varronia curassavica as antimicrobial agents. Both plants are native to the Brazilian territory and listed among the 71 plants of the National List of Medicinal Plants of Interest to the Brazilian Unified Health System (Brasil, 2009). This list encourages the use of complementary therapies in the public health system and promotes research with these medicinal plants, guaranteeing their correct and safe use by the population (Marmitti et al., 2015).

The findings on the antimicrobial activity of Mikania laevigata plant extract and fractions in planktonic conditions are shown in Table 1. All Mikania laevigata (ML) extracts/fractions tested presented MIC values ranging from 250 to $4000 \mu \mathrm{g} / \mathrm{ml}$ and MBC/MFC values ranging from 1000 to $>4000 \mu \mathrm{g} / \mathrm{ml}$, showing inhibitory activity against E. faecalis (MIC 1000-4000 $\mu \mathrm{g} / \mathrm{ml}$ ) and A. israelii (MIC 250-2000 $\mu \mathrm{g} / \mathrm{ml}$ ), except for the ML aqueous fraction (MLAF) for $A$. israelii. The ML ethyl acetate fraction (MLEAF) affected the growth of all microorganisms tested and the ML hexane fraction (MLHF) affected E. faecalis, A. israelli, and C. albicans. MLEAF had the best effect compared to the other ML extracts/fractions. A. israelii was highly sensitive to MLEAF $(\mathrm{MIC}=250 \mu \mathrm{g} / \mathrm{ml})$, MLCHE $(\mathrm{MIC}=330 \mu \mathrm{g} / \mathrm{ml})$, and MLHF $(\mathrm{MIC}=330 \mu \mathrm{g} / \mathrm{ml})$. The $\mathrm{ML}$ extracts/fractions with the best results for MBC/MFC were chosen considering their performance against each microorganism for the biofilm assays: MLCHE for A. israelii, MLHF for C. albicans and A. israelii, and MLEAF for all microorganisms (Table 1). 
Table 1. Minimum inhibitory concentration (MIC) and minimal bactericidal/fungicidal concentration (MBC/MFC) of Mikania laevigata (ML) extract and fractions against resistant oral pathogens.

\begin{tabular}{|c|c|c|c|}
\hline \multirow{2}{*}{ Extract/Fraction } & \multirow{2}{*}{ Microorganisms } & MIC & MBC/MFC \\
\hline & & $(\mu \mathrm{g} / \mathrm{ml})$ & $(\mu \mathrm{g} / \mathrm{ml})$ \\
\hline \multirow{4}{*}{ ML crude hydroethanolic extract (MLCHE) } & E. faecalis & 4000 & $>4000$ \\
\hline & P. aeruginosa & $>4000$ & $>4000$ \\
\hline & A. israelii & 330 & 2000 \\
\hline & C. albicans & $>4000$ & $>4000$ \\
\hline \multirow{3}{*}{ ML Aqueous fraction (MLAF) } & E. faecalis & 4000 & $>4000$ \\
\hline & P. aeruginosa & $>4000$ & $>4000$ \\
\hline & A. israelii & $>4000$ & $>4000$ \\
\hline \multirow{5}{*}{ ML Hexane fraction (MLHF) } & C. albicans & $>4000$ & $>4000$ \\
\hline & E. faecalis & 4000 & $>4000$ \\
\hline & P. aeruginosa & $>4000$ & $>4000$ \\
\hline & A. israelii & 330 & 1000 \\
\hline & C. albicans & 4000 & $>4000$ \\
\hline \multirow{3}{*}{ ML Butanol fraction(MLBF) } & E. faecalis & 4000 & $>4000$ \\
\hline & P. aeruginosa & $>4000$ & $>4000$ \\
\hline & A. israelii & 2000 & $>4000$ \\
\hline \multirow{4}{*}{ ML Ethyl acetate fraction (MLEAF) } & C. albicans & $>4000$ & $>4000$ \\
\hline & E. faecalis & 1000 & 1000 \\
\hline & P.aeruginosa & 4000 & 4000 \\
\hline & A. israelii & 250 & 4000 \\
\hline \multirow{4}{*}{ Chlorhexidine digluconate (CHX) } & C. albicans & 4000 & 4000 \\
\hline & E. faecalis & 6.5 & 9,8 \\
\hline & P. aeruginosa & 39 & 78 \\
\hline & A. israelii & 1.2 & 1.2 \\
\hline Amphotericin $B(A B)$ & C. albicans & 0.16 & 0.49 \\
\hline
\end{tabular}

All tested Varronia curassavica (VC) extracts/fractions demonstrated inhibitory activity against $E$. faecalis and $A$. israelii, with MIC values ranging from 410 to $4000 \mu \mathrm{g} / \mathrm{ml}$ and MBC/MFC values ranging from 500 to $>4000 \mu \mathrm{g} / \mathrm{ml}$. C. albicans and $P$. aeruginosa were not affected by any VC extract or fraction. VC ethyl acetate fraction (VCEAF) had the best effect compared to other VC fractions. A. israelli was highly sensitive to VCEAF (MIC $=410 \mu \mathrm{g} / \mathrm{ml})$, VCHF (MIC $=500$ $\mu \mathrm{g} / \mathrm{ml})$, and VCCHE $(\mathrm{MIC}=500 \mu \mathrm{g} / \mathrm{ml})$, and because of this effect, VCEAF, VCCHE, and VCHF were chosen for the biofilm assays (Table 2). 
Table 2. Minimum inhibitory concentration (MIC) and minimal bactericidal/fungicidal concentration (MBC/MFC) of Varronia curassavica (VC) extract and fractions against resistant oral pathogens.

\begin{tabular}{|c|c|c|c|}
\hline \multirow{2}{*}{ Extract/Fraction } & \multirow{2}{*}{ Microorganisms } & MIC & MBC/MFC \\
\hline & & $(\mu \mathrm{g} / \mathrm{ml})$ & $(\mu \mathrm{g} / \mathrm{ml})$ \\
\hline \multirow{4}{*}{ VC crude hydroethanolic extract (VCCHE) } & E. faecalis & 4000 & $>4000$ \\
\hline & P. aeruginosa & $>4000$ & $>4000$ \\
\hline & A. israelii & 500 & 500 \\
\hline & C. albicans & $>4000$ & $>4000$ \\
\hline \multirow{3}{*}{ VC Aqueous fraction (VCAF) } & E. faecalis & 4000 & $>4000$ \\
\hline & P. aeruginosa & $>4000$ & $>4000$ \\
\hline & A. israelii & 4000 & $>4000$ \\
\hline \multirow{5}{*}{ VC Hexane fraction (VCHF) } & C. albicans & $>4000$ & $>4000$ \\
\hline & E. faecalis & 4000 & $>4000$ \\
\hline & P. aeruginosa & $>4000$ & $>4000$ \\
\hline & A. israelii & 500 & 2000 \\
\hline & C. albicans & $>4000$ & $>4000$ \\
\hline \multirow{3}{*}{ VC Butanol fraction (VCBF) } & E. faecalis & 4000 & $>4000$ \\
\hline & P. aeruginosa & $>4000$ & $>4000$ \\
\hline & A. israelii & 2600 & $>4000$ \\
\hline \multirow{4}{*}{ VC Ethyl acetate fraction (VCEAF) } & C. albicans & $>4000$ & $>4000$ \\
\hline & E. faecalis & 4000 & $>4000$ \\
\hline & P. aeruginosa & $>4000$ & $>4000$ \\
\hline & A. israelii & 410 & $>4000$ \\
\hline \multirow{4}{*}{ Chlorhexidine digluconate (CHX) } & C. albicans & $>4000$ & $>4000$ \\
\hline & E. faecalis & 6.5 & 9.8 \\
\hline & P. aeruginosa & 39 & 78 \\
\hline & A. israelii & 1.2 & 1.2 \\
\hline Amphotericin $B(A B)$ & C. albicans & 0.16 & 0.49 \\
\hline
\end{tabular}

Figure 1 indicates box-whisker plots of the antibiofilm activity of the plant extracts and fractions. MLEAF (5XMBC) eliminated $E$. faecalis, A. israelii, and $P$. aeruginosa biofilms after $24 \mathrm{~h}$ of exposure. The same was observed for MLCHE and MLHF for A. israelii. None of the tested extracts or fractions eliminated the $C$. albicans biofilm. The 10x MLEAF obtained the best results against $C$. albicans biofilms, although without statistical difference between $5 x$ MLHF, 10XMLHF, and 5X AB. VCCHE and VCHF significantly reduced the microbial growth on the $A$. israelli biofilms, however, only $10 x \mathrm{VCHF}$ was able to eliminate them. 

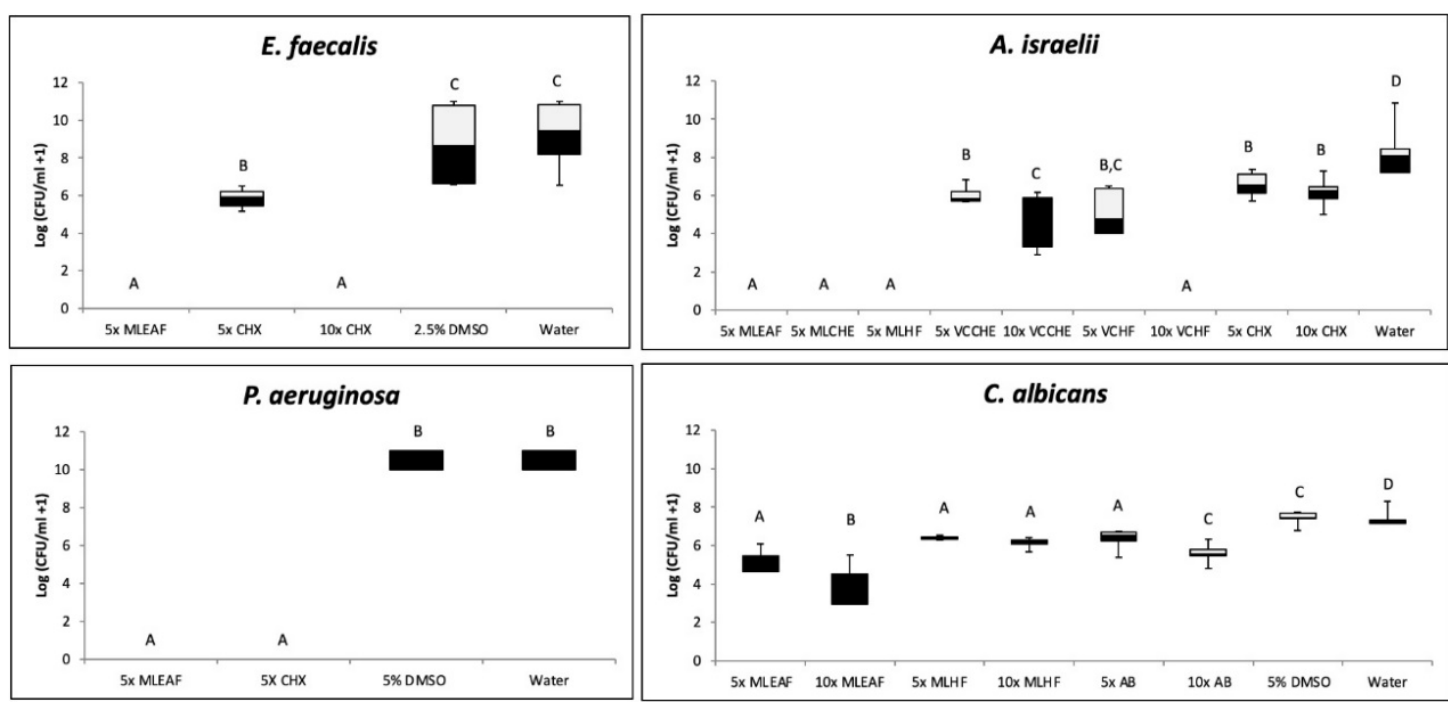

Figure 1. Box-whisker plots of the anti-biofilm activity of the extracts and fractions of Mikania laevigata and Varronia curassavica against pathogenic microorganisms. Different capital letters $(A, B, C, D)$ show statistical difference among the groups, including the controls (DMSO and water), according to MannWhitney tests. Bars indicate minimum and maximum values. Black and white boxes indicate lower and upper quartiles, respectively. Line in the middle of boxes is median MLCHE - Mikania laevigata crude Hydroethanolic extract, MLAF - Mikania laevigata Aqueous fraction, MLHF; Mikania laevigata Hexane fraction, MLBF - Mikania laevigata Butanol fraction, MLEAF - Mikania laevigata Ethyl acetate fraction, $\mathrm{CHX}$ - Chlorhexidine digluconate, AB - Amphotericin B, VCCHE - Varronia curassavica crude Hydroethanolic extract, VCAF - Varronia curassavica Aqueous fraction, VCHF - Varronia curassavica Hexane fraction, VCBF - Varronia curassavica Butanol fraction, VCEAF - Varronia curassavica Ethyl acetate fraction.

Following a similar antimicrobial methodology to that used in the current study, Yatsuda et al. (2005) found MIC and MBC/MFC values between 12.5 and $400 \mu \mathrm{g} / \mathrm{ml}$ for ML hydroethanolic extracts and hexane and ethyl acetate fractions against streptococci strains. The authors also observed that the extracts and fractions tested were able to inhibit the adherence of mutans streptococci cells to glass surfaces at sub-MIC levels (three times lower than their MIC values). The $\mathrm{ML}$ hexane fraction was the most effective antibacterial agent, displaying MIC and MBC values between 12.5 and $100 \mu \mathrm{g} / \mathrm{ml}$. In the present study, the ML hexane fraction (MLHF) presented strong inhibitory activity against $A$. israelii $(\mathrm{MIC}=330 \mu \mathrm{g} / \mathrm{ml}$ ) and weak activity against $E$. faecalis $(\mathrm{MIC}=4000 \mu \mathrm{g} / \mathrm{ml}$ ) and $C$. albicans (MIC $=4000 \mu \mathrm{g} / \mathrm{ml}$ ). The ML ethyl acetate fraction (MLEAF) was the most effective antimicrobial agent, showing activity for all microorganisms tested (MIC 250$4000 \mu \mathrm{g} / \mathrm{ml})$. Although there are no standard values when considering the inhibition level of the plant materials, many authors have considered them as strong inhibitors (MIC lower than 500 $\mu \mathrm{g} / \mathrm{ml}$ ), moderate inhibitors (MIC between $600 \mu \mathrm{g} / \mathrm{ml}$ and $1500 \mu \mathrm{g} / \mathrm{ml}$ ), and weak inhibitors (MIC above $1600 \mu \mathrm{g} / \mathrm{ml}$ ) (dos Santos et al., 2006; Passari et al., 2014). Analyzing the ML composition through phytochemical screening, the major compounds isolated from ML extracts were coumarin, coumaric acid, terpenes, sesquiterpenes, diterpenes, and organic acids (Limberger et al., 2001) Coumarin 1,2benzopyrone is considered the main substance isolated from ML, and it can be used as a biomarker for pharmacological formulations (Sartoratto et al., 2004; Yatsuda et al., 2005). Secondary metabolites, such as the derivatives of cinnamic acid and kaurane diterpenes have also demonstrated synergic pharmacological effects (Sartoratto et al., 2004; Duarte et al., 2007).

One of the first studies to evaluate the antimicrobial activity of Varronia curassavica (VC) was developed by Carvalho et al. (2004) using the agar plate diffusion method. The authors found that VC essential oil was able to inhibit $88.8 \%$ of Gram-positive strains, $93.3 \%$ of yeast strains, including Candida albicans, and $20 \%$ of Gram-negative strains tested. VC essential oil inhibited Enterococcus faecalis growth with an MIC of $200 \mu \mathrm{g} / \mathrm{ml}$ (Meccia et al., 2009). In another study, Pseudomonas aeruginosa was sensitive, by the agar diffusion method, to 11 of 
the 23 VC extracts, with the best results for the VC extract with 25\% ethanol. In addition, the VC hydroethanolic extract inhibited Pseudomonas aeruginosa in MIC assays at a concentration of $1000 \mu \mathrm{g} / \mathrm{ml}$ (Michielin et al., 2009). In the current study, P. aeruginosa and C. albicans growth were not affected by any of the VC extract/fractions tested, however, the VC crude extract and fractions exhibited effects on E. faecalis (MIC of $4000 \mu \mathrm{g} / \mathrm{ml}$ ) and A. israelii growth (MIC between $410-4000 \mu \mathrm{g} / \mathrm{ml}$ ). These discrepancies between our results and the literature might occur due to differences in the extraction methods and solvents used to obtain VC extracts. Other factors could be related to the collection site and season that the leaves were collected, which may influence the presence and concentrations of the plant metabolites in the extracts (Siqueira \& Rôças, 2008). VC essential oil, obtained by the hydrodistillation method, showed inhibitory activity against Staphylococcus aureus, Bacillus cereus, Candida albicans, Candida krusei, and Escherichia coli, with MIC values between 64 and $512 \mu \mathrm{g} / \mathrm{ml}$ (Rodrigues et al., 2012). Several investigators have studied the chemical composition of VC (Mello \& Santos, 2002; Boussaada et al., 2008; Michielin et al., 2009), and the antibacterial activity of VC extracts has been associated with the presence of sesquiterpenes, such as bisabolol and farnesyl acetate 1, tannins, and flavonoids (Santos \& Mello, 2002) or the presence of aromatic compounds, such as eugenol, detected in the VC ethanolic extract composition (Davino et al., 1989; Boussaada et al., 2008). A synergistic effect between bisabolol and eugenol could also explain the antimicrobial activity of VC (Boussaada et al., 2008; Michielin et al., 2009). In the present study, chlorhexidine digluconate and Amphotericin B were used as positive controls. $\mathrm{CHX}$ is the current gold standard for antibacterial tests (Gomes et al., 2013) and its effectiveness has been reported in biofilm assays (Matias et al.,2013). In addition, AB has been employed as positive control in studies on antifungal activity (Youssef et al., 2014).

Finally, considering the wide range of existing natural extracts native to South America, with diverse therapeutic properties (Tribess et al.,2015; Pereira et al., 2004), the current research shows the antimicrobial/antibiofilm effect and importance of two native plants. In addition, the selection of treatment using medicinal plants may be due to the availability of the local flora, but also because this type of treatment is considered healthier and more natural, with no adverse effects (Boccolini \& Boccolini, 2020; Santos et al., 2011). However, further studies on the topic are still needed.

\section{CONCLUSION}

In summary, Mikania laevigata ethyl acetate fraction is an efficient antimicrobial/antibiofilm agent against resistant pathogens and could be indicated for the treatment of persistent dental infections.

\section{ACKNOWLEDGMENTS}

This study would like to thank Coordenação de Aperfeiçoamento de Pessoal de Nível Superior - Brasil (Capes) for financial support (Finance Code 001).

\section{REFERENCES}

Balouiri M, Sadiki M, Ibnsouda SK. Methods for in vitro evaluating antimicrobial activity: a review. J Pharm Anal. 2016;6(2):71-9. http://dx.doi.org/10.1016/j.jpha.2015.11.005. PMid:29403965.

Boccolini PMM, Boccolini CS. Prevalence of complementary and alternative medicine (CAM) use in Brazil. BMC Complement Med Ther. 2020;20(1):51. http://dx.doi.org/10.1186/s12906-020-2842-8. PMid:32054461.

Boussaada O, Ammar S, Saidana D, Chriaa J, Chraif I, Daami M, Helal AN, Mighri Z. Chemical composition and antimicrobial activity of volatile components from capitula and aerial parts of Rhaponticumacaule DC growing wild in Tunisia. Microbiol Res. 2008;163(1):87-95. http://dx.doi.org/10.1016/j.micres.2007.02.010. PMid:17482441.

Brasil. Relação nacional de plantas de interesse ao Sistema Único de Saúde [Internet]. Brasília: Ministério da Saúde; 2009 [cited 2020 Sep 23]. Available from: https://www.saude.gov.br/acoes-e- 
programas/programa-nacional-de-plantas-medicinais-e-fitoterapicos-ppnpmf/politica-e-programanacional-de-plantas-medicinais-e-fitoterapicos/plantas-medicinais-de-interesse-ao-sus-renisus

Carvalho PM Jr, Rodrigues RFO, Sawaya ACHF, Marques MOM, Shimizu MT. Chemical composition and antimicrobial activity of the essential oil of Cordia verbenaceaDC. J Ethnopharmacol. 2004;95(23):297-301. http://dx.doi.org/10.1016/j.jep.2004.07.028. PMid:15507352.

Cogulu D, Uzel A, Oncag O, Eronat C. PCR-based identification of selected pathogens associated with endodontic infections in deciduous and permanent teeth. Oral Surg Oral Med Oral Pathol Oral Radiol Endod. 2008;106(3):443-9. http://dx.doi.org/10.1016/j.tripleo.2008.03.004. PMid:18547832.

Davino SC, Giesbrecht AM, Roque NF. Antimicrobial activity of kaurenoic acid derivatives substituted on carbon-15. Braz J Med Biol Res. 1989;22(9):1127-9. PMid:2517587.

Duarte MC, Leme EE, Delarmelina C, Soares AA, Figueira GM, Sartoratto A. Activity of essential oils from Brazilian medicinal plants on Escherichia coli. J Ethnopharmacol. 2007;111(2):197-201. http://dx.doi.org/10.1016/j.jep.2006.11.034. PMid:17210236.

Gandolfo ES, Hanazaki N. Etnobotânica e urbanização: conhecimento e utilização de plantas de restinga pela comunidade nativa do distrito do Campeche (Florianópolis, SC). Acta Bot Bras. 2011;25(1):16877. http://dx.doi.org/10.1590/S0102-33062011000100020.

Gomes BP, Vianna ME, Zaia AA, Almeida JF, Souza-Filho FJ, Ferraz CC. Chlorhexidine in endodontics. Braz Dent J. 2013;24(2):89-102. http://dx.doi.org/10.1590/0103-6440201302188. PMid:23780357.

Hartwig BR, Rodrigues DS, Oliveira JR. Erva Baleeira: uma possibilidade real da Sociobiodiversidade para modelos sustentáveis de produção. Holos. 2020;3:1-21.

Hassler M. World plants: synonymic checklists of the vascular plants of the world (version Nov 2018). In: Roskov Y, Ower G, Orrell T, Nicolson D, Bailly N, Kirk PM, Bourgoin T, DeWalt RE, Decock W, Van Nieukerken E, Penev L, editors. Species 2000 \& ITIS Catalogue of Life, 2020-09-01 Beta. Leiden, The Netherlands: Species 2000: Naturalis; 2020 [cited 2020 Sep 23]. Available from: www.catalogueoflife.org/col

International Plant Name Index. The Royal Botanic Gardens, Kew: INPI; 2012 [cited 2020 Sep 23]. Available from: https://www.ipni.org/

Jardim Botânico do Rio de Janeiro. Varronia curassavica Jacq. Rio de Janeiro; 2020 [cited 2020 Sep 23]. Available from: http://reflora.jbrj.gov.br/reflora/floradobrasil/FB105435

Limberger RP, Aboy AL, Bassani VL, Moreno PRH, Ritter MR, Henriques AT. Essential oils from four Mikania species (Asteraceae). J Essent Oil Res. 2001;13(4):225-8. http://dx.doi.org/10.1080/10412905.2001.9699676.

Marmitti DJ, Rempel C, Goettert MI, Couto e Silva A. Plantas medicinais da Relação Nacional de Plantas de Interesse ao Sistema Único de Saúde com potencial antiparasitário. Scientia Amazonia [Internet]. 2015 [cited 2020 Sep 23];4(3):54-62. Available from: http://www.scientia-amazonia.org

Massunari L, Novais RZ, Oliveira MT, Valentim D, Dezan-Junior E, Duque C. Antimicrobial activity and biocompatibility of the Psidium cattleianum extracts for endodontic purposes. Braz Dent J. 2017;28(3):372-9. http://dx.doi.org/10.1590/0103-6440201601409. PMid:29297559.

Matias EFF, Alves EF, Nascimento Silva MK, Carvalho VRA, Coutinho HDM, Costa JGM. The genus Cordia: botanists, ethno, chemical and pharmacological aspects. Rev Bras Farmacogn. 2015;25(5):542-52. http://dx.doi.org/10.1016/j.bjp.2015.05.012.

Matias EFF, Santos KKA, Falcão-Silva VS, Siqueira-Junior JP, Costa JGM, Coutinho HDM. Modulation of the norfloxacin resistance in Staphylococcus aureus by Cordia verbenacea DC. Indian J Med Res. 2013;137(1):178-82. PMid:23481069.

Meccia G, Rojas LB, Velasco J, Díaz T, Usubillaga A, Arzola JC, Ramos S. Chemical composition and antibacterial activity of the essential oil of Cordia verbenacea from the Venezuelan Andes. Nat Prod Commun. 2009;4(8):1119-22. http://dx.doi.org/10.1177/1934578X0900400821. PMid:19768996.

Michielin EMZ, Salvador AA, RiehI CAS, Smânia A Jr, Smânia EFA, Ferreira SRS. Chemical composition and antibacterial activity of Cordia verbenacea extracts obtained by different methods. Bioresour Technol. 2009;100(24):6615-23. http://dx.doi.org/10.1016/j.biortech.2009.07.061. PMid:19683436.

Miranda TM, Hanazaki N. Conhecimento e uso de recursos vegetais de restinga por comunidades das Ilhas do Cardoso (SP) e de Santa Catarina (SC), Brasil. Acta Bot Bras. 2008;22(1):203-15. http://dx.doi.org/10.1590/S0102-33062008000100020. 
Oliveira ER, Menini L No. Levantamento etnobotânico de plantas medicinais utilizadas pelos moradores do povoado de Manejo, Lima Duarte - MG. Rev Bras PI Med. 2012;14(2):311-20. http://dx.doi.org/10.1590/S1516-05722012000200010.

Passari LM, Scarminio IS, Bruns RE. Experimental designs characterizing seasonal variations and solvent effects on the quantities of coumarin and related metabolites from Mikania laevigata. Anal Chim Acta. 2014;821:89-96. http://dx.doi.org/10.1016/j.aca.2014.03.003. PMid:24703218.

Passos GF, Fernandes ES, Cunha FM, Ferreira J, Pianowski LF, Campos MM, Calixto JB. Anti-inflammatory and anti-allergic properties of the essential oil and active compounds from Cordia verbenacea. J Ethnopharmacol. 2007;110(2):323-33. http://dx.doi.org/10.1016/j.jep.2006.09.032. PMid:17084568.

Pereira RC, Oliveira MTR, Lemos GCS. Plantas utilizadas como medicinais no município de Campos de Goytacazes - RJ. Rev Bras Farmacogn. 2004;14:37-40. http://dx.doi.org/10.1590/S0102$695 \times 2004000300015$.

Persoon IF, Buijs MJ, Özok AR, Crielaard W, Krom BP, Zaura E, Brandt BW. The mycrobiome of root canal infections is correlated to the bacteriome. Clin Oral Investig. 2017;21(5):1871-81. http://dx.doi.org/10.1007/s00784-016-1980-3. PMid:27771826.

Pinto JS, Oliveira AKM, Fernandes V, Matias R. Ethnobotany and popular culture in the use of plants in settlements on the southern edge of southern Pantanal Mato Grosso. Biosci J. 2017;33(1):193-203. http://dx.doi.org/10.14393/BJ-v33n1a2017-33106.

Rodrigues FFG, Rodrigues FFG, Almeida SCX, Campos AR, Oliveira LGS, Saraiva ME, Cabral MES, Costa JGM. Chemical composition, antibacterial and antifungal activities of essential oil from Cordia verbenacea DC leaves. Pharmacogn Rev. 2012;4(3):161-5. http://dx.doi.org/10.4103/09748490.99080. PMid:22923954.

Roldão EF, Witaicenis A, Seito LN, Hiruma-Lima CA, Di Stasi LC. Evaluation of the antiulcerogenic analgesic activities of Cordia Verbenacea DC. (Boraginaceae). J Ethnopharmacol. 2008;119(1):94-8. http://dx.doi.org/10.1016/j.jep.2008.06.001. PMid:18588967.

Santos RL, Guimarães GP, Nobre MSC, Portela AS. Análise sobre a fitoterapia como prática integrativa no Sistema Único de Saúde. Rev Bras Plantas Med. 2011;13(4):486-91. http://dx.doi.org/10.1590/S1516-05722011000400014.

Santos SC, Krueger CL, Steil AA, Kreuger MR, Biavatti MW, Wisniewski A J. Characterisation of guaco medicinal extracts, Mikania laevigata and Mikania glomerata, and their effects on allergic pneumonitis. Planta Med. 2006;72(8):679-84. http://dx.doi.org/10.1055/s-2006-931577. PMid:16755468.

Santos, SC, Mello CP. Taninos. In: Simões CMO, editor. Farmacognosia: da planta ao medicamento. 4. ed. Porto Alegre: UFRGS; 2002.

Sartoratto A, Machado ALM, Delarmelina C, Figueira GM, Duarte MCT, Rehder VLG. Composition and antimicrobial activity of essential oils from aromatic plants used in Brazil. Braz J Microbiol. 2004;35(4):275-82. http://dx.doi.org/10.1590/S1517-83822004000300001.

Siqueira JF Jr, Rôças IN. Clinical implications and microbiology of bacterial persistence after treatment procedures. J Endod. 2008;34(11):1291-301.e3. http://dx.doi.org/10.1016/j.joen.2008.07.028. PMid:18928835.

The Plant List. The Plant List. Version 1.1 [Internet]. 2013 [cited 2020 Sep 23]. Available from: http://www.theplantlist.org/

Tribess B, Pintarelli GM, Bini LA, Camargo A, Funez LA, Gasper AL, Zeni AL. Ethnobotanical study of plants used for therapeutic purposes in the Atlantic Forest region, Southern Brazil. J Ethnopharmacol. 2015;164:136-46. http://dx.doi.org/10.1016/j.jep.2015.02.005. PMid:25680844.

Yatsuda R, Rosalen PL, Cury JA, Murata RM, Rehder VLG, Melo LV, Koo H. Effects of Mikania genus plants on growth and cell adherence of mutans streptococci. J Ethnopharmacol. 2005;97(2):183-9. http://dx.doi.org/10.1016/j.jep.2004.09.042. PMid:15707750.

Youssef D, Shaala L, Mohamed G, Badr J, Bamanie F, Ibrahim S. Theonellamide G, a potent antifungal and cytotoxic bicyclic glycopeptide from the Red Sea marine sponge Theonellas winhoei. Mar Drugs. 2014;12(4):1911-23. http://dx.doi.org/10.3390/md12041911. PMid:24694570. 


\section{Author's contributions}

LM - conceptualization, data duration, formal analysis, funding acquisition, methodology, writing of the original draft, writing, review and editing of the final version.

ACAS - methodology, writing of the original draft, writing, review and editing of the final version. PFKD - methodology, writing of the original draft, writing, review and editing of the final version. JAS - methodology, writing of the original draft, writing, review and editing of the final version. LVSS - conceptualization, data duration, formal analysis, project administration, supervision, writing of the original draft, writing, review and editing of the final version.

EDJ - conceptualization, data duration, formal analysis, project administration, supervision, writing of the original draft, writing, review and editing of the final version.

CD - conceptualization, data duration, formal analysis, funding acquisition, methodology, project administration, supervision, writing of the original draft, writing, review and editing of the final version. 